\title{
Research on the Ideological and Political Education in the College Students Management Work
}

\author{
Liu ying \\ ChongQing college of electronic engineering, Chongqing, China \\ bestdewy@yahoo.com.cn
}

Keywords: Ideological and Political Education, College Students, ManageHment Work

\begin{abstract}
Society is in progress and people's thinking is also changing, in order to improve the ideological and political system of colleges and universities, so we should reform the ideological and political education system for college students. The importance of ideology and politics has become the reason why many scholars have studied the ideological and political education. In order to adapt the traditional model of ideological and political education to the new educational system, the management system of the students' ideological and political education management at the present stage is formulated, and the management system conforms to the needs of modern students. From the management of the main body to the scope of management to make a consistent reform, training students in the healthy development of political thought.
\end{abstract}

\section{Introduction}

It is an important part of the current university education, and its success or failure is directly related to the fact that the college students are an important successor and a new force in the cause of socialist modernization in our country, do ideological and political education of college students and improve the ideological and political accomplishment of college students The future of our socialist cause. At present, China is in a critical period of socialist construction, the speed of social transformation is accelerating, and the international situation is changing rapidly. The ideological and political education of college students is facing a severe new situation. The level of ideological and political management of college students is the key factor influencing the effectiveness of ideological and political education of college students. Do a good job in solving the problems in the ideological management of college students, and strive to improve the ideological and political management system for college students to improve the level of ideological and political management of college students is to improve the ideological and political quality of college students, and the formation of the socialist core value system The key of ideological and moral consciousness. This paper explores the necessity of ideological and political management of college students, analyzes the problems existing in the ideological and political management of college students, and puts forward some countermeasures on how to improve the level of ideological and political management of college students, on the level of students' ideological and political management.

\section{The Ideological and Political Education of College Students}

The Content of Ideological and Political Education Management. "Ideological and political education management" pointed out that the educators in order to achieve the ideological and political education goals, according to the established management system for the corresponding ideological and political education of college students organized and planned supervision and implementation of the ideological and political improvement. Ideological and political education management has a certain degree of particularity, the student as the main body it is to play the role of education to the school as the main body is the manager of the management reference system. The management of ideological and political education of college students is a special practice of management, both of which have the dual attributes of school education and social management.

The Characteristics of Ideological and Political Education Management. Ideological and political education management goal is to enable students to cultivate a sound personality, make it a 
useful talent for the community, and the traditional management objectives to achieve short-term management effect in the nature of a significant difference. The goal of ideological and political education management will not change due to the change of educational environment and the understanding of college students' own ideological education. This nature determines the particularity of ideological and political education management objectives. The application of scientific methods for the development of college students in Chinese political and cultural education requirements, with the most advanced management methods through the practice of students to achieve healthy thinking and good personality.

\section{The Problems of College Students' Ideological and Political Education Management}

Management System Is Not Perfect. The management system of college students' political education is the sum of the implementation system and the leadership system. The managers of the ideological education in colleges and universities have the right to decide on this system and solve the problem of the selection of the person in charge and the management of the university system. However, with the reform of the social education system, the ideological and political system of college students should follow the progress of society and improve the content and requirements of the education system and the needs of modern society there is a gap. The manager of the new educational system requires that the manager of the system be responsible for the ideological education of the students, but the actual educational environment is that the system manager is held by the principal and the secretary, leading to the deviation of the educational thought, and the students accepted two different thoughts the concept of political education is bound to lead to the emergence of students in the state of division. At present, the latest education system to the decision to grant the full powers to the principal, but only part of the university principals to do ideological responsibility for students, most of the principal cannot think from the student's point of view, did not put the appropriate human and material resources to support college students of the ideological and political education, so that students ideological and political education system is imperfect.

Management Methods Are Relatively Simple. The management methods of college students' ideological and political education not only can achieve the goal of students thinking management can also improve management efficiency. However, the current high school students' education management approach is relatively simple problem, mainly in the management method is not comprehensive use and management methods lack the application of modern technology in two aspects. Management methods, including psychological, economic, legal, administrative and educational, etc. to use these five methods to make it play a role, but China is more emphasis on administrative methods, different circumstances cannot be taught by people led to management The concept of backward, cannot form an active atmosphere of the organization, the management of the system manager had a hindrance. Management methods are not good at the use of the target management law, put aside the modern technology side, will cause the deviation of the target, the ideological and political education of students indifferent, will inevitably lead to the management system cannot be effectively implemented.

\section{The Necessity of Ideological and Political Education for College Student}

The Development of Colleges and Universities Needs to Strengthen the Work of Ideological and Political Education. As an important part of the work of cultivating talents, the student affairs work directly reflects the educational quality and management level of colleges and universities. In the context of deepening the reform of higher education in our country, the acceptance of higher education has become an important way of human capital investment. It not only requires colleges and universities to provide the specialized knowledge needed by educators, but also requires high quality education services in colleges and universities to improve the overall management benefits to become a university must solve the problem, student service management efficiency is one of them. Therefore, colleges and universities must adapt to the requirements of the development of the situation, constantly updated their own school ideas and ideas. The concept of running a university 
is about the development of a university model, the pursuit of goals, social responsibility aspects of the system, including the University of ideals, beliefs, ideas and the guiding ideology of the school, the development of the program of action and other aspects of the basic content. Almost all of the world's leading universities in their school philosophy are unique, both unique, leading the trend, but also with the times, the courage to change, shining bright light. College student affairs and school teaching, research, etc., is an important part of higher education. In the new era of very complex and intense competitive environment, colleges and universities to achieve their own healthy and sustainable development, we must have a distinctive characteristics of their own school philosophy, and through the development of detailed planning and take a series of effective measures To protect the school concept can be effectively transformed into the school process of specific actions in order to attract students to school to receive education, a school without a student is difficult to achieve the school's own mission, vision and specific goals.

The "People-Oriented" Service System Needs to Strengthen Ideological and Political Education. People-oriented, is to emphasize the respect of the people themselves, the value of human and the meaning of the affirmative, it contains to promote the comprehensive development of human-oriented profound meaning, pointed out that the ideological and political education in colleges and universities and the basic task of the basic task the ideological and political education in colleges and universities to truly implement the spirit of people-oriented, is to promote and realize the overall development of students as the central proposition, ideals and beliefs as the core of education to focus on patriotism education, based on basic moral education, respect for college students the subject position and independent personality, so that the work of college students close to the reality of life of students, fundamentally enhance the ideological and political education targeted and effective, attractive and appeal.

The Needs of the Community Needs to Strengthen Ideological and Political Education. With the continuous development of economy and society, the demand for talent is also increasing. College students can not only learn professional knowledge, but also to improve their own quality training capacity. The quality of college students and the problem of capacity is equally important, a person's quality, you can see a person's taste, a person's cultivation connotation. Ideological and political education is a purposeful, planned, organized educational activity that helps educate educators in the right direction. Colleges and universities meet the economic and social development of the increasingly high demand for talent to achieve their own survival and development, first of all in the student affairs management to do ideological and political education, and constantly improve their own quality of personnel training. And attach great importance to the ideological and political education of college students is our party's fine traditions and important political advantages, in the economic and social development has played a very important role. In short, the ideological and political education in the management of student affairs in colleges and universities has a very important status and value. College students are very valuable human resources, is the hope of the nation, is the future of the motherland. However, at present, the management of college students' affairs in our country is incompatible with the development of the situation. It is an extremely important and important task to strengthen and improve the ideological and political education of college students.

\section{The Solutions of Ideological and Political Education Management of College Students}

Strengthen the reform and construction of the management system of ideological and political education for college students. In order to improve the ideological and political management system of college students, it is necessary to reform the ideological education system of the students who have organized and implemented the party committee. Change the principal, the party's old ideas to achieve a tacit understanding between the two, in order to establish a new education system. The president should develop all aspects of students' moral, intellectual, and labor, which is the trend of modern educational nature, and should have the responsibility of managing students' ideological and political education, and put students' ideological and political education into the same position as teaching and scientific research. Students 'ideological and political education decision-making 
power in the hands of the school party committee, change the school party committee concept, improve students' ideological and political effect. Train students' correct thinking. It can be the ideological and political management of college students are assigned to the principal and head of the hands of the head, respectively to establish a principal and head of the head of the student political and ideological education system of work.

Realize the scientific evaluation of students' ideological and political education evaluation management. The establishment of ideological and political education evaluation management platform, the management of students' ideological and political education so that students of ideological and political education by the management of the main command and control, in order to make the assessment management system for students to play the role of ideological education, assessment management system must be scientific first of all, to the scientific evaluation of indicators as a student ideological and political education assessment of the prerequisite for the management of the actual ideological education of students, reflecting the ideological and political education of college students. To achieve the scientific assessment of assessment methods must be in accordance with the principles of scientific assessment, adhere to the dynamic and static combination of the way. Because the student's thought is to change with the change of time, so the assessment management should be different periods of the ideological state of the students to develop the management mechanism, so you can get a relatively accurate assessment of the effect. In addition, to achieve an effective assessment of management feedback, one is to assess the subject and the object cannot deceive each other, to cooperate with each other, the second is to strengthen the management of the assessment methods. The third level departments and different departments have a sense of mutual cooperation, so as to achieve the smooth progress of ideological and educational work of college students.

\section{Conclusion}

The 21st century is the era of college students 'ideological education is full of challenges, so the reform of students' ideological education system should be carried out. In order to meet the needs of modern society, we must reform the ideological education system of college students. The management of ideological and political education of college students not only needs to meet the challenges of the present society, but also make positive improvements to the traditional educational ideas, create more diverse and open educational management system, improve students' ideological and political education The efficiency of management work, access to education management breakthroughs, training students healthy and positive personality and way of thinking for the motherland to cultivate modern society talents to make positive efforts.

\section{References}

[1] Huifang Zhou: Journal of Yangzhou University, Vol. 6 (2004) No 53, p.25-26

[2] Hongli Zhang: Journal of Heihe, Vol. 12 (2005) No 27, p.74-76

[3] Qin Guo: Journal of Chifeng University, Vol. 1 (2006) No 33, p.11-14

[4] Jieming Liu: Guangxi Normal University, Vol. 3 (2007) No33, p.121-124

[5] Jia Xinzhang, Li Jingyuan. Chinese Higher Education Research, Vol. 6 (2014) No 53, p.25-26 